\title{
The Effectiveness of Herbarium as a Learning Medium on Compound Leaf Material for Students' Achievement in Biology
}

\author{
Dahlia* and Masdi Janiarli
}

\author{
Department of Biological Education, University of Pasir Pengaraian, Riau \\ *Corresponding author. Email: dahlia_8959@yahoo.com
}

\begin{abstract}
This research aims to find out the effectiveness of herbarium used as a medium of learning on compound leaf material toward the learning achievement for the third semester of Biology students at University of Pasir Pengaraian. This type of research is Quasi experiment. The design used is pretest-posttest control group design. The population in the study is all students of the Faculty of teacher training and education in Biology Education Study Program. The research sample is the third semester students of the Faculty of teacher training and education University of Pasir Pengaraian Biology Education Study Program who are assigned with purposive sampling technique. Data analysis techniques are validity tests, normality tests, homogeneity tests, and t-tests based on the software of SPSS 16. Testdata posttest class experiments and control classes obtained sig values. (2-tailed) $=0.006$ smaller than the limit used which is $5 \%$ (sig. $<0.05$ ), meaning there is a significant difference in the average learning outcomes of both classes. The value of the experiment class's mean pretest and posttest grades is 37.50 and the control class is 27.72 . The value of the experiment class posttest means greater than the control class of $70.43>60.09$. Therefore, it can be concluded that the use of herbarium as a medium of learning in compound leaf material toward the learning achievement the third semester of Biology students at University of Pasir Pengaraian is more effective than without the use of herbarium media.
\end{abstract}

Keywords: Herbarium, Learning media, Learning outcomes.

\section{INTRODUCTION}

Education is inseparable from learning activities. Learning in nature is a process of change in human being [1]. There are six components in education, namely educational objectives, educators, educational subjects, educational materials or materials, educational tools, and educational environments called educational factors that are interconnected and support one another [2].

A teacher should be able to prepare active, efficient, fun, stimulating and challenging learning so that students do not get bored easily. One of the efforts that can be done is the development and innovation of learning media. Media is a stimulus for students for the learning process [3]. Variations in learning can be in the form of learning media. Problems in learning can be solved by the use of alternative media that is interesting and in accordance with the object to be described [4].
The general purpose of plant morphology learning is that students can understand, apply and communicate knowledge related to the features, functions and development of growth organs such as stem, leaf, root, flower and fruit and modification. Hamiyah [1] mentioning the obscurity of the material conveyed can be helped by presenting the media as an intermediary.

Herbarium is one of the learning media suitable for plant morphological material. According to [5] the herbarium is a warehouse of plant specimens collected, dried and mounted on handmade sheets of paper. According to [6] learning using the herbarium media of students' memories will be more permanent because the media herbarium is the real thing not just through images.

Based on observations, plant morphology material is explained from the teaching book, using media from plant samples brought to class. This is not maximal, because the sample of plants carried does not last long, in addition if the plant samples are continuously carried 
will damage the population of the plant. In addition, the herbarium in the laboratory has never been used as a support for learning activities. Therefore, researchers are interested in using herbarium media to teach the morphological concept of compound leaves.

The term intermediary in the media is used because of the function of the media as an intermediary or the introduction of a message from the sender to the receiver [7]. Based on the above definition, the function of the media is as an intermediary in conveying, and the media can make learners to understand and to be motivated [8]. According to [9] learning media is an intermediary that can be enabled to channel messages, stimulate the minds, feelings and wills of students.

The function of learning media is as a source of learning, namely as a channeler, messenger, message or knowledge liaison from educators to learners. In addition, the media also serves to clarify the meaning of a word, term, sign or symbol. Capture, store, display, recreate an object or event so that it can be reused when needed [3]. Leaf preserve learning media is visual media. Visual learning media is a type of media used solely on the senses of vision of learners [10].

Herbarium is a collection of preserved plant specimens that are essential for the field of botany, especially in the systematics. They can also be important historical documents [11]. Herbarium has two meanings, first defined as the storage of plant specimens both dry and wet. As a study of plants especially for noosing and classification. Herbarium is closely related to botanical gardens, research institutions, or education [12].

The function of herbarium is, as the basis for the study of flora and vegetation because on the label herbarium contains the data needed for that purpose. This is important in the identification of plants, as the referee of the correct name, and as a data bank [12].

Herbarium media helps students identify other plants that have similar morphological features. With herbarium media students can see firsthand the original shape of the plant. Herbarium media is very practical, economical and can be carried anywhere in the classroom as well as in the laboratory [13]. With herbarium media students can see in real life the plants that exist in nature and associate them with accepted concepts with direct observation [14].

\section{RESEARCH METHODS}

The type of research used is Quasi experiment. The research design used is Pretest-Posttest control group design. This research sample is Third semester students of the biology education study program of Pasir Pengaraian University which is determined by purposive sampling technique. The instrument used in the form of tests is in the form of objective questions.

The implementation phase in accordance with the design used is starting by giving pretest to both sample classes to see the initial abilities of the students. After that, given treatment to both sample classes, the experiment class learned using herbarium media, while the control class learned without the use of herbarium media. Upon completion, both sample classes will be given a posttest to see the student's study results after treatment [15]. The learning results obtained from the experimental class of 26 students and control class of 39 students were then analyzed with normality test stages, homogeneity test and $t$ test.

\section{RESULTS AND DISCUSSION}

\subsection{Results}

\subsubsection{Spread Normality Test}

Test normality test was calculated using the Kolmogorov-Smirnov formula with the help of SPSS version 16.

Table 1. Spread Normality Test Results

\begin{tabular}{|l|c|c|}
\hline \multicolumn{1}{|c|}{ Class } & P & Description \\
\hline Pretest Experiment & 0,100 & \multirow{2}{*}{$\begin{array}{c}\text { P }>0,05 \\
\text { =Normal }\end{array}$} \\
\cline { 1 - 2 } Pretest Control & 0,094 & \\
\cline { 1 - 2 } Posttest Experiment & 0,176 & \\
\cline { 1 - 1 } Posttest Control & 0,403 & \\
\hline
\end{tabular}

Table 1 shows that the index obtained from the experiment class normality test and the control class > sig. 0.05. Therefore, it can be stated that the data are distributed normally.

\subsubsection{Results Variance Homogeneity Test}

The homogeneity test is a test of similarities with the help of SPSS version 16.

Table 2. Variance Homogeneity Test

\begin{tabular}{|l|c|c|}
\hline \multicolumn{1}{|c|}{ Class } & P & Description \\
\cline { 1 - 1 } Pretest Experiment & 0,837 & \multirow{2}{*}{$\begin{array}{c}\text { P }>0,05 \\
=\text { Homogen }\end{array}$} \\
\cline { 1 - 1 } Pretest Control & 0,331 & \\
\cline { 1 - 2 } Posttest Experiment & & \\
\cline { 1 - 2 } Posttest Control &
\end{tabular}

Table 2 shows that the experiment class variance homogeneity test score and control $>$ of the sig level. $5 \%$, it can be said that the distribution of data is homogeneous. 


\subsubsection{Experiment Class and Control Class Pretest Test-t Data}

The significance value of the second pretest value of the sample class was $0.870>0.05$. It can then be concluded that there were no significant differences in the pretest of both sample classes.

Table 3. Test-t Pretest Value

\begin{tabular}{|c|c|c|c|}
\hline Class & Average & Sig. & $\boldsymbol{\alpha}(\mathbf{5 \%})$ \\
\cline { 1 - 2 } Experiment & 32,93 & \multirow{2}{*}{0,870} & 0,05 \\
\hline Control & 32,37 & & \\
\hline
\end{tabular}

\subsubsection{Test-t posttest Experiment Class and Control Class}

From the calculation results, we obtained a posttest result significance value from both sample classes of $0.006<0.05$. Then there were significant differences in the posttest of both sample classes, as shown in table 4 .

Table 4. T-test Posttest value

\begin{tabular}{|l|c|c|c|}
\hline \multicolumn{1}{|c|}{ Class } & Average & Sig. & $\boldsymbol{\alpha ~ ( 5 \% )}$ \\
\cline { 1 - 2 } Experiment & 70,43 & 0,006 & 0,05 \\
\hline Control & 60,09 & & \\
\hline
\end{tabular}

\subsubsection{Hypothesis Testing}

Increased experiment class pretest and posttest scores by 37.50 , and control class by 27.72 . Judging by the mean value of the experiment class posttest is greater than the control class of $70.43>60.09$. Therefore, herbarium media is effective to improve the learning outcomes of students of biology education courses. For more details can be seen in figure 1 .

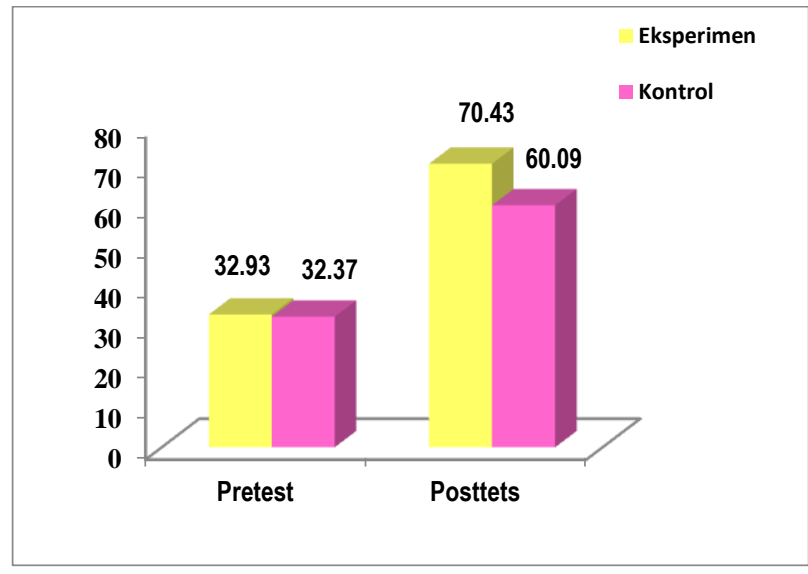

Figure 1. Pretest and posttest values

\subsection{DISCUSSION}

Significant differences from posttest values in both classes can be seen from the mean values of both classes. The experiment class mean score of 70.43 is greater than the control class mean value of 60.09 Meanwhile, the difference between the mean pretest and posttest of the experiment class was 37.50 and the control class was 27.72. Therefore, it can be concluded that the use of herbarium media on compound leaf material more effectively improves learning outcomes than without the use of herbarium media. Mertha [16] states that the use of herbariums will be more enjoyable and more effective in achieving the expected competencies and objectives. Based on research [17] it was obtained that based on a comparison of herbarium media pretest and posttest scores can be declared effective in significantly improving students' understanding.
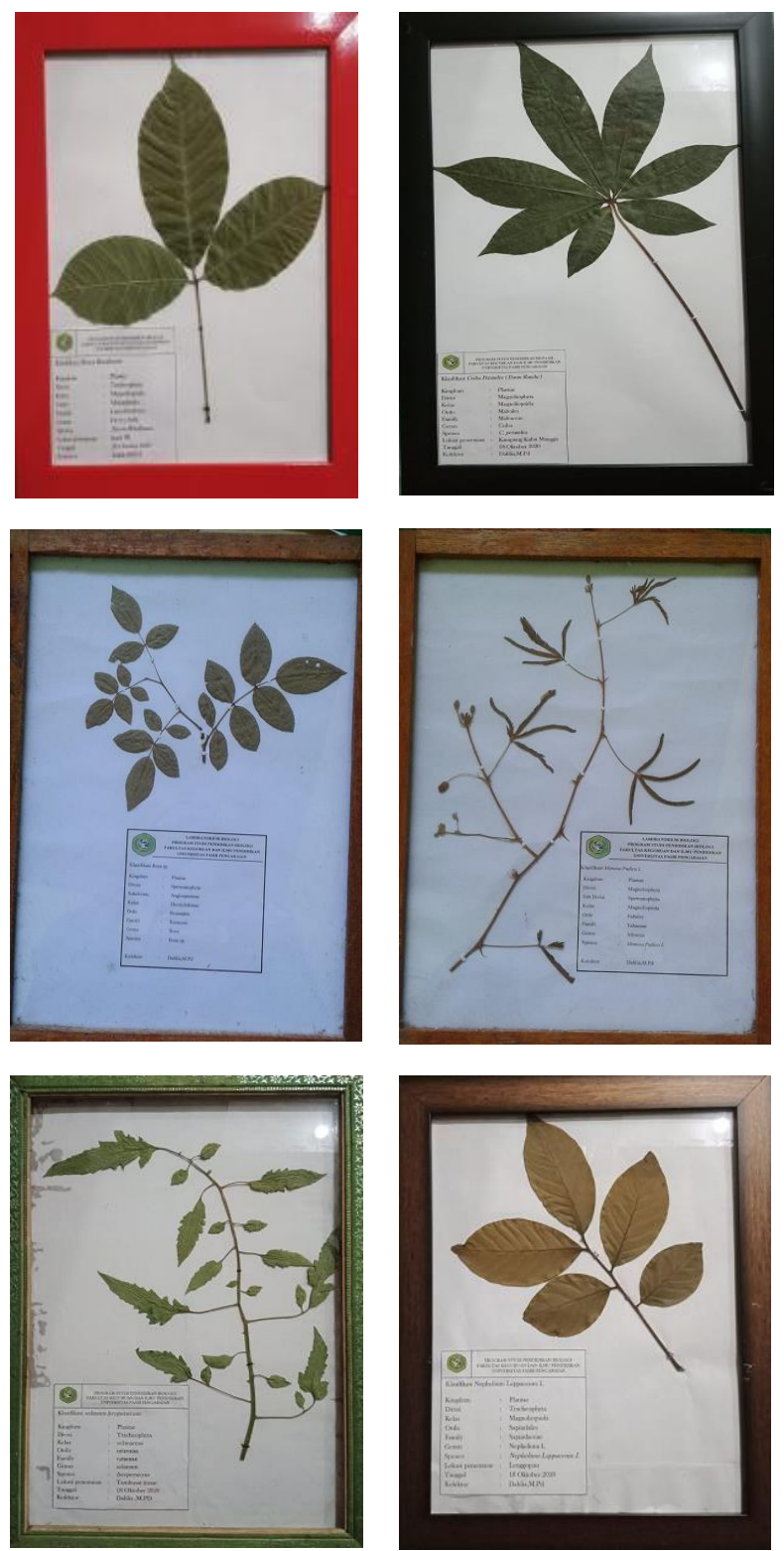

Figure 2. Compound leaf herbarium

The results of the experiment class study are higher than in the control class, because the use of 
herbarium learning media can affect the student's learning activities. Students are more active when using herbarium learning media. This is in line with [14], which states the use of herbarium and insectarium can affect students' learning activities. This is mainly in the activity of listening to the teacher's explanation and the activity of asking the teacher. In addition, according to [17] herbarium media is able to increase students' attention to learning materials because students can directly link with learning objects.

Herbarium media is effective because it can make it easier to understand a concept [18]. The study found that herbarium media is effective for learning about Plantae, because the media used is organized based on the student environment. Research by Hasugian [13] obtained that herbarium media can improve students' learning outcomes because it can facilitate the achievement of the goal to understand and remember information or messages contained in the herbarium. We can see an example of the appearance of some compound leaf herbarium in figure 2 .

\section{CONCLUSIONS}

In summary, the use of herbarium as a learning medium in compound leaf material against the study results of students of semester 3 Biology in Universitas of Pasir Pengaraian is more effective than without the use of herbarium media.

\section{ACKNOWLEDGMENTS}

The authors acknowledge Rena Lestari as chairman of the Biological Education Studies Program who has given permission to do this research in biology education study program. We also expressed our gratitude to the research members for being willing to help and provide valuable input in the writing of this article.

\section{REFERENCES}

[1] Hamiyah dan Jauhar, M. 2014. Strategi Belajar Mengajar Di Kelas. Prestasi Pustaka: Jakarta.

[2] Syafril dan Zen, Z.2012. Pengantar Pendidikan. Sukabina Press: Padang. [3] C. Baier, J-P. Katoen, Principles of Model Checking, MIT Press, 2008.

[3] Rusman., Kurniawan,D dan Riyana,C.2011. Pembelajaran Berbasis Teknologi Informasi dan Komunikasi. Raja Grafindo Persada: Jakarta.

[4] Septiani, K.S, Noorhidayati, Riefani, M.K. 2020. The Validity of Question Wheel "Karunia"
Learning Media in the Archaebacteria and Eubacteria Students of Class X IPA of SMAN 7 Banjarmasin. Bio-Inoved. 1 (2): 7-13.

[5] Seshagirirao, K, Harikrishnanaik, L, Venumadhav, K, Nanibabu, B, Jamir, B, Ratnamma, B,K, Jena, R and Babarao, D.K. 2016. Preparation Of Herbarium Specimen For Plant Identification And Voucher Number. Education Article. Roxburghia 6(1-4): 111-119.

[6] Herman, H. 2016. Efektivitas Penggunaan Spesimen Segar Sebagai Media Pembelajaran Pada Konsep Jamur Terhadap Hasil Belajar Peserta Kelas X SMAN 1 Maiwa Kabupaten. Skripsi. Fakultas Tarbiyah dan Keguruan UIN Alauddin Makasar.

[7] Asyhar, R. 2011. Kreatif Mengembangkan Media Pembelajaran. Gaung Persada Press: Jakarta.

[8] Dikrullah. 2018. Pengembangan Herbarium Book Sebagai Media Pembelajaran Biologi Pada Mata Kuliah Struktur Tumbuhan Tinggi. Jurnal Biotek. 6 (1): $15-25$

[9] Suyanto dan Jihad, A. 2013. Menjadi Guru Profesional. Esensi Erlangga: Jakarta.

[10] Djamarah,S.B.danZain,A. 2013. Strategi Belajar Mengajar. Rineka Cipta: Jakarta.

[11] Flannery, M.C. 2013. Plant Collections Online: Using Digital Herbaria in Biology Teaching. Bioscene. 39 (1): 3-9.

[12] Murni, P., Muswita., Harlis., Yelianti, U., Kartika, W.D. 2015. Lokakarya pembuatan herbarium untuk pengembangan media pembelajaran biologi MAN Cendikia Muaro Jambi. Jurnal Pengabdian pada Masyarakat. 2 (30): 1-6.

[13] Hasugian, H dan Napitupulu, M.A. 2016. Perbedaan Hasil Belajar Spermatophyta Siswa Yang Diajar Menggunakan Media Herbarium Dan Tanpa Herbarium Di Kelas X SMA Negeri 2 Kisaran. Jurnal Pelita Pendidikan. 4 (3): 40-44.

[14] Afifah, N., Sudarmin, Widianti, T. 2014. Efektifitas Penggunaan Herbarium dan Insektarium Pada Tema Klasifikasi Mkhluk hidup Sebagai Suplemen Media Pembelajaran IPA Terpadu Kelas VII MTs.Unnes Science Education Journal. 3 (2):494501.

[15] Lufri. 2007. Staregi Pembelajaran Biologi Teori, Praktek dan Penelitian. UNP Press: Padang.

[16] Mertha, I.G., Idrus, A.I., Ilhamdi, M.L dan Zulkifli. 2018. Pelatihan Teknik Pembuatan Herbarium 
Kering Dan Identifikasi Tumbuhan Berbasis Lingkungan Sekolah Di SMAN 4 Mataram. Jurnal pendidikan dan pengabdian masyarakat. 1 (1): 8287.

[17] Afif, M, Wisanti, dan Isnawati. 2014. Pengembangan Herbarium Paku-pakuan Sebagai MediA Realita Dalam Materi Keanekaragaman Tumbuhan Untuk Siswa Kelas X SMA. BioEdu Berkala ilmiah Pendidikan biologi. 3 (3): 472-478.
[18] Mualimaturrochmah, Retnoningsih, A, dan Rahayuningsih, M. 2020. Pteridophyta Herbarium Based on Science, Technologi, Engineering, and Mathematic in Plantae Material in Senior High School. Journal of Innovative Science Education. 9 (2): 126-135. 